TECHNICAL TRANSACTIONS 9/2018

ARCHITECTURE AND URBAN PLANNING

DOI: $10.4467 / 2353737$ XCT.18.130.8969

SUBMISSION OF THE FINAL VERSION: 17/7/2018

\author{
Tomasz Węcławowicz (iD) orcid.org/0000-0002-9560-483X \\ tomasz@weclawowicz.pl \\ Faculty of Architecture and Fine Arts, Andrzej Frycz Modrzewski Krakow University
}

\title{
How Do They See Us from Afar: British Scholars and Romanesque and Gothic Architecture in Lesser Poland
}

JAK WIDZĄ NAS Z DALEKA: BRYTYJSCY UCZENI A ROMAŃSKA I GOTYCKA ARCHITEKTURA W MAŁOPOLSCE

\begin{abstract}
Romanesque and Gothic architecture in Poland cannot compete with European medieval masterpieces even though before the $15^{\text {th }}$ century, medieval buildings in the Kingdom were created by foreign mastermasons who came from far afield. Until recently, Gothic and especially Romanesque churches did not attract attention of British scholars. It is now rewarding for the Polish reader, that thanks to Paul Crossley, Alexandra Gajewski, Zoë Opačić, Agnieszka Sadraei and primarily Eric Fernie, Polish medieval architecture appears for the first time in international literature. Encouragingly, even if it has been created on the outskirts of the Latin culture, it is now seen as being closely anchored in the European artistic universum of that time.
\end{abstract}

Keywords: Lesser Poland, Medieval architecture, British scholars,

\section{Streszczenie}

Romańska i gotycka architektura w Polsce nie może pretendować do najwybitniejszych realizacji europejskich. Należy też pamiętać, iż aż do wieku XV wieku średniowieczne budowle wznosili u nas muratorzy obcy, którzy przybyli z Italii z Węgier lub krajów Cesarstwa. Do niedawna nasze kościoły gotyckie, a zwłaszcza romańskie, nie przyciągały uwagi brytyjskich naukowców. Dla polskiego czytelnika satysfakcjonujące jest to, że od kilku lat dzięki Paulowi Crossleyowi, Alexandrze Gajewski, Zoë Opačić, Agnieszce Sadrei, ale przede wszystkim dzięki Ericowi Ferniemu, polska średniowieczna architektura po raz pierwszy pojawiła się w międzynarodowej literaturze naukowej w całej swej prowincjonalnej okazałości, lecz ściśle związana z artystycznym universum ówczesnej Europy.

Słowa kluczowe: małopolska, architektura średniowiecza, naukowcy brytyjscy 
Romanesque and Gothic architecture in Poland cannot compete with the medieval European architectural masterpieces, which inspired and documented the stylistic evolution in the Middle Ages. The universalism of these transformations can be clearly traced across Europe, from the Iberian Peninsula to the eastern limits of Latin civilization. It was through Poland that the eastern boundaries of the Romanesque style extended running from Gdansk through Kałdus, Płock, Czerwińsk, Szczebrzeszyn to Przemyśl. The borders of Gothic style stretched even further to the east - from Lithuania into the Ruthenian lands (Latyczów). Built on the outskirts these were not foundations of provincial quality because they were created by foreign master-masons who came from far afield. Some of them have been hypothetically identified, for instance the construction of the Romanesque monastery church in Czerwińsk, probably involved craftsmen from the Italian workshop of Viligelmo de Modena [9; 10, pp. 215-226]. Foreign masters, such as Nikolas Werner from Prague and Hungarians from Zips/Spiš (Johann Csipser, among others) contributed to the construction of the large, $14^{\text {th }}$-century Gothic basilicas in the capital city of Krakow [eg. 15]. It was not until the mid$15^{\text {th }}$ century that Polish-sounding surnames (Marcin Proszko) appeared in the accounts of the construction of churches near Krakow founded by Jan Długosz, a Canon of the cathedral and a distinguished historiographer. Despite geographical distance from the most important artistic centres, the cathedrals, monasteries and parish churches erected in Poland faithfully reproduced the spatial arrangements, the stylistic character and the architectural detail

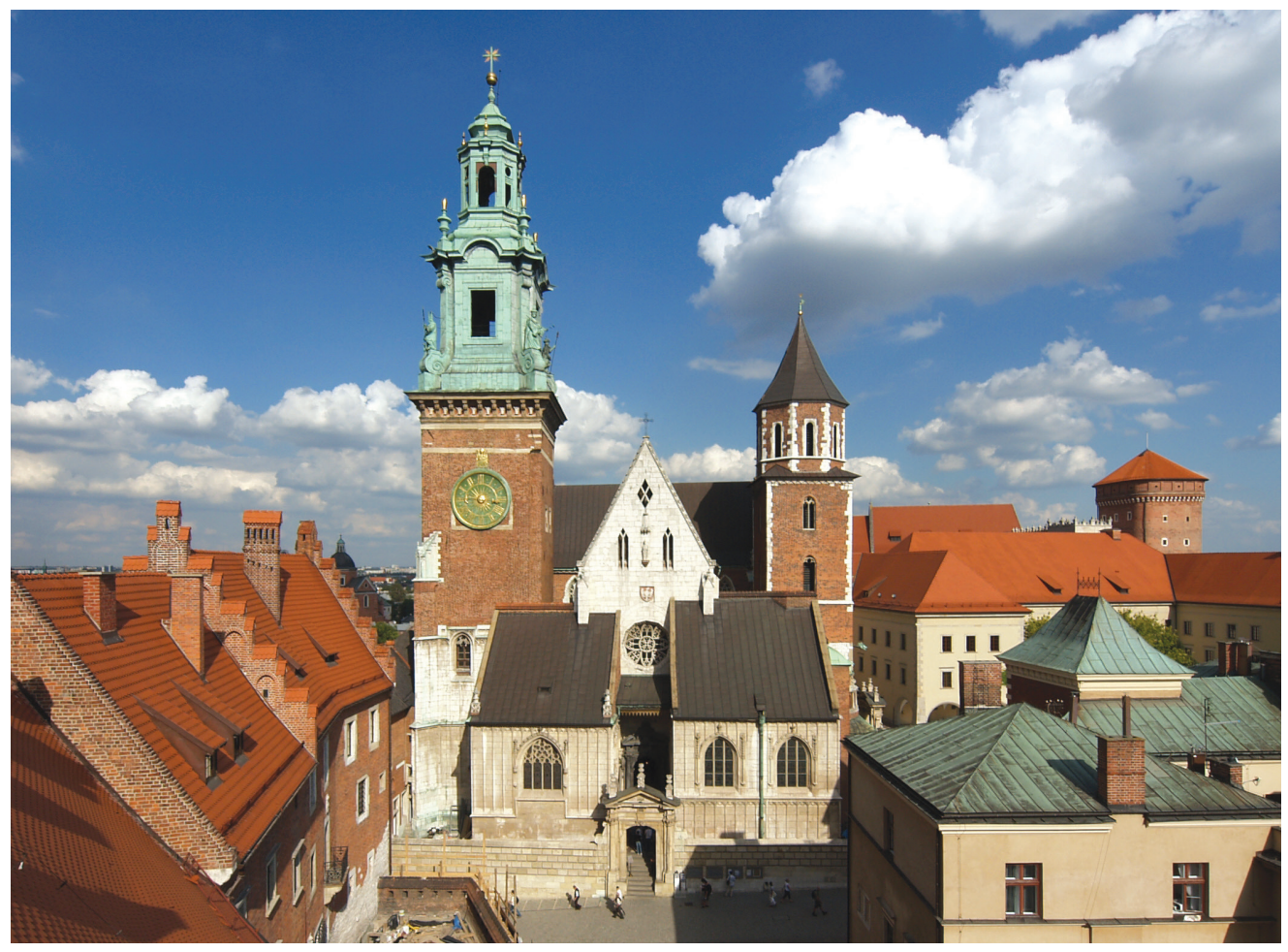

Fig. 1. Krakow, cathedral church, Gothic west front (photo by P. Guzik, after [16]) 
typical of their European counterparts. The only provincial aspects were: diminished size, some simplifications and a small number of such buildings.

In both Romanesque and Gothic periods, the richest and most densely populated Lesser Poland with its capital in Krakow was distinguished from other provinces of the kingdom. This is where the building stock was at its most abundant and impressive, at the same time displaying a multitude of artistic influences and trends that are well-recognized by modern art historians. No wonder that the spectacular Gothic projects from the time of the reign of King Kazimir the Great in Poland attracted the attention of Prof. Paul Crossley. Exactly 45 years ago in 1973, he defended his doctoral thesis written under the supervision of Prof. Peter Kidson at the Courtauld Institute of Art in London. The title was The Architecture of Kazimir the Great. Twelve years later, his book, featuring a Polish summary, was published in Poland by the publishing house of the Royal Castle in Wawel [3] ${ }^{1}$. Crossley's work was an important and major breakthrough in our state of knowledge, and methodological approach to the so-called "King Kazimir architecture". Even though only a young scholar, Crossley delivered a model analysis of Kazimir's foundations, identified and defined the stylistic phases of Krakow cathedral linking them to stylistic changes in Central Europe, and providing relevant and illuminating comparative material. He mapped out the place of $14^{\text {th }}$-century Krakow in the evolution of European architecture from the Classical into Late Gothic style. In his research, Crossley focused on Krakow cathedral as formally and ideologically a most complete Polish royal foundation. It was a real Königskirche, which beside functioning as an episcopal seat, became also a coronation church and the royal necropolis. Crossley devoted an extensive chapter to the unique presbytery of St Mary's church, the first so-called Hochchor in Lesser Poland. It must be emphasized that, even though the formal inspirations for the interior layout came from Upper Rhineland, it was in Central Europe that the Hochchor type reached the greatest height: $30-33 \mathrm{~m}$ in Prague churches and 24-28m in Krakow ones.

As already a widely-recognized professor of the Courtauld Institute of Art and a member of the British Academy ${ }^{2}$, Crossley continued his research on Polish monuments, primarily Krakow cathedral, concentrating on its ideological content as Königskirche [2, pp. 49-68; 4, pp. 31-45]. He also encouraged his students to work on Polish Gothic $\left[12^{3} ; 14\right.$, pp. 83-116] and inspired Polish researchers with his modern analyses [16].

In 2011 Prof. Paul Crossley and Dr Agnieszka Sadraei were instrumental in organising the annual conference of the British Archaeological Association in Krakow on the subject of "Medieval Art, Architecture and Archaeology in Krakow and Lesser Poland" [13]. The conference brought together Polish and international scholars and the local audience had an opportunity to listen to several papers by British scholars including Prof Crossley himself,

1 Young readers should be made aware that in communist Poland it was standard to take so long to publish a book. To publish a paper in an academic journal took approximately three years.

2 Professor Paul Crossley FBA, FSA, for many years he lectured at the Courtauld Institute of Art in London and later he was also a Slade Professor of the Trinity College at Cambridge University.

3 Dr Agnieszka Roznowska-Sadraei BA, MA, MSc, PhD - worked for several years as Properties Curator for English Heritage and has recently taken up the post with Historic Royal Palaces as Buildings Curator at the Tower of London. 


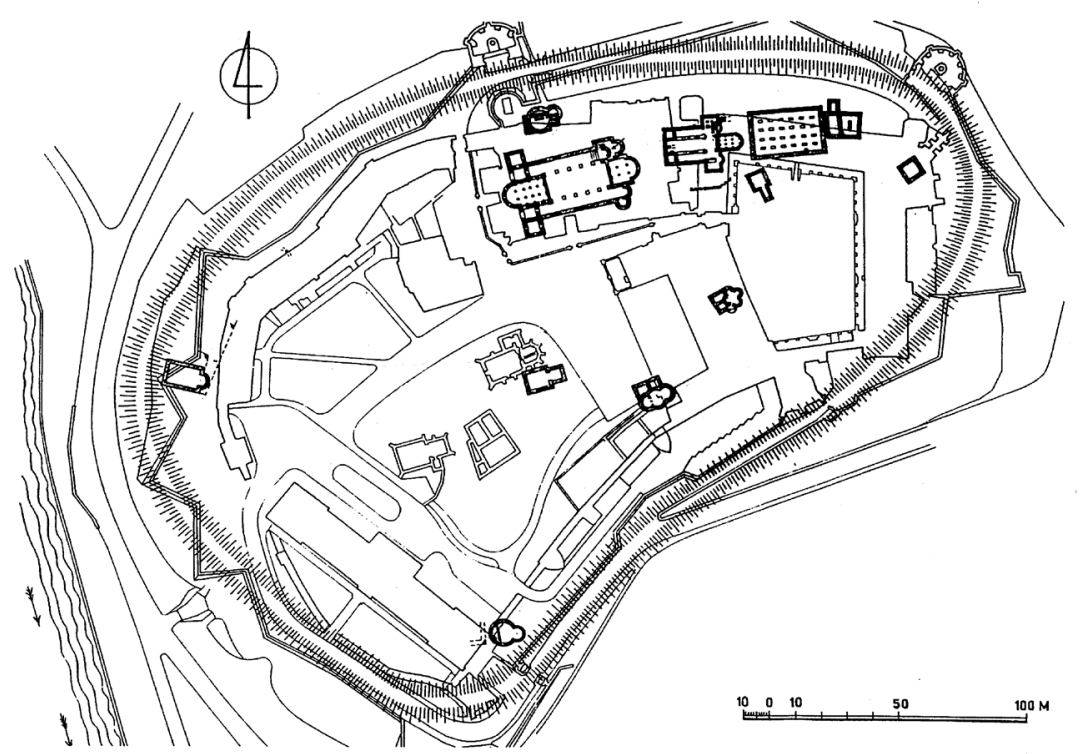

Fig. 2. Krakow, Romanesque churches on the cathedral hill in the middle of the $12^{\text {th }}$ c. (source: [16])

as well as Dr. Zoë Opačićt, Dr. Aleksandra Gajewski ${ }^{5}$ and, above all, Professor Eric Fernie, a member of the British Academy, and a world-renowned expert in Romanesque architecture ${ }^{6}$.

Paul Crossley had a truly erudite introductory lecture. Zoë Opačić developed Paul Crossley's insights on the relations of architecture and liturgical ceremonies in the cathedral churches of Krakow and Prague [11, pp. 95-117]. Alexandra Gajewski, according to her specialization, focused on Cistercian monasteries in Lesser Poland [7, pp. 175-197; 8, pp. 212-217]. But in the context of this review it is Eric Fernie's paper on St Andrew's church in Krakow that deserves special attention.

This church is an impressive, if somewhat puzzling foundation and has not been thoroughly studied and investigated, and research conclusions on various aspects of its architecture have been controversial. A unique transept basilica, it has a nave reduced to one bay, and its Westwerk was added later and built into the next bay to the west. Fernie found examples of other basilicas with a short nave and argued that their territorial dispersal in Europe cannot be considered as simply coincidental because of close interrelations within the Latin Church. This

4 Dr Zoë Opačić BA, MA, PhD, FSA, is a Senior Lecturer in the History and Theory of Architecture, at the Department of History of Art of the Birkbeck College, University of London. She is also an Editor of the 'Journal of the British Archaeological Association'.

5 Dr Aleksandra Gajewski PhD, FSA is the specialist in mediaeval architecture. She has lectured at the Courtauld Institute of Art, at Birkbeck College, at the Victoria \& Albert Museum, and as Visiting Assistant Professor at the University of Michigan, Ann Arbor. She has just completed a European project at the Centro de Ciencias Humanas y Sociales in Madrid as a Senior Researcher. She has published widely on the Cistercian architecture in France, the Holy Roman Empire and Bohemia. She is also the Reviews Editor in 'The Burlington Magazine'.

6 Professor Eric Fernie CBE, FRSE, FBA, FSA is a famous Scottish art historian. He was the Director of the Courtauld Institute of Art (1995-2003) and the President of the Society of Antiquaries of London (2004-2007). 
seems especially insightful because in the Polish kingdom (even in Krakow) and especially in the Romanesque period, not only masons but above all the clergy, including the majority of the Episcopate, were mostly foreigners. Perhaps for this reason the architecture created on the borders of Latin christianitas, grew out of and was firmly anchored in an international context. In the local comparative context, Fernie pointed to a group of Romanesque small, single -nave churches erected in Lesser Poland in the $12^{\text {th }}$ century, and distinguished two of them - in Jędrzejów and Prandocin, due to their planform featuring a double apse. Therefore, paradoxically, it is not the Romanesque cathedral basilicas, but humble churches of Lesser Poland together with St Andrew's, a reduced basilica that first made appearance in British and, simultaneously, international scholarship [6, pp. 17-27].

Soon Fernie's fascination with Polish and Central European Romanesque bore fruit in the shape of a monumental volume and a comprehensive academic compendium published in 2014 [5]. It successfully replaced the earlier one written by Kenneth J. Conant and published in the same Pelican History of Art series [1]. In this publication Fernie adopted an innovative methodological approach reflected in the layout of the chapters, which combine problematic issues - definition of style (chapter: Definitions), types of buildings (chapter: Themes), methods of analysis (chapter: Methods) as well as chronology (chapters: Early, Middle and Late phases) and topography (chapters on the Empire, regions of France, Italy, Iberian Peninsula, British Isles, Central Europe and Scandinavia). He also devoted a few extensive sections to Poland and it should be emphasized that this is the first review of Polish Romanesque monuments on an international forum. Furthermore, the narrative is complete with an indispensable and concise historical introduction explaining to English-speaking readers the circumstances of the reception of Christianity by Polish rulers at the end of the $10^{\text {th }}$ century and establishment of the independent Polish church metropolis in 1000 during the visit of Emperor Otto III in Gniezno (Greater Poland). Such an introduction is important as a focus on the time when the first masonry buildings were constructed in the kingdom. Amongst these buildings, palaces with chapels at Ostrów Lednicki (Poznan), in Giecz, and later in Wiślica deserve special mention. The first and earliest of these palaces includes a building with baptismal fonts in the pavement. Fernie thinks that the Polish phenomenon of palace complexes with baptisteries buildings could have inspired the patrons in the Empire and quotes Galliano near Como as an analogy for the unique baptistery at Ostrów Lednicki, even though the Lombardain example is a slightly later foundation. In turn, he juxtaposes the complex of round churches on the cathedral hill in Krakow with Moravian rotundas and argues that they all may have a common source in the Ottonian Empire, to the North or South of the Alps. Fernie's analysis of these pre-Romanesque buildings is the more impressive since they survive mostly as mere remnants of foundations or lower walls. While discussing palatial types of those well-preserved monuments, which can be thoroughly investigated, Fernie draws attention to different artistic influences in the southern (the Lesser Poland province) and northern (Greater Poland province) parts of the Polish kingdom: the Meuse Valley region inspired Greater Poland, while Upper Rhineland and Alsace - Lesser Poland via Bohemia. Therefore, the double apse basilicas, such as the cathedral church in Krakow (before 1079 to 1142) and the collegiate church in Tum (Middle Poland, c. 1136-1161) repeated the planform of the cathedral church in Prague (1060-1096). Their 
primary model was the cathedral church in Mainz, the archdiocese of Prague. The surprising influences from Upper Rhineland are noticeable even in the ornamentation of the arcades of the portal and windows in the small church in Prandocin. These resemble ornamentation details in the monumental cathedral in Speyer. The closest parallels for the collegiate church in Opatów can be found in Alsace. In turn, the Benedictine church in Mogilno in Greater Poland has close analogies with churches in the Meuse Valley, in Celles and Hastieres. Taking all this into account Fernie aptly concludes: „Despite Poland having remained independent while Bohemia became a duchy of Empire, the types of buildings and evident changes are remarkably similar in the two centuries" [5, p. 167]. He therefore reiterates the conclusion from his previous publication, namely that provincial architecture at the eastern boundaries of christianitas grew out of international context.

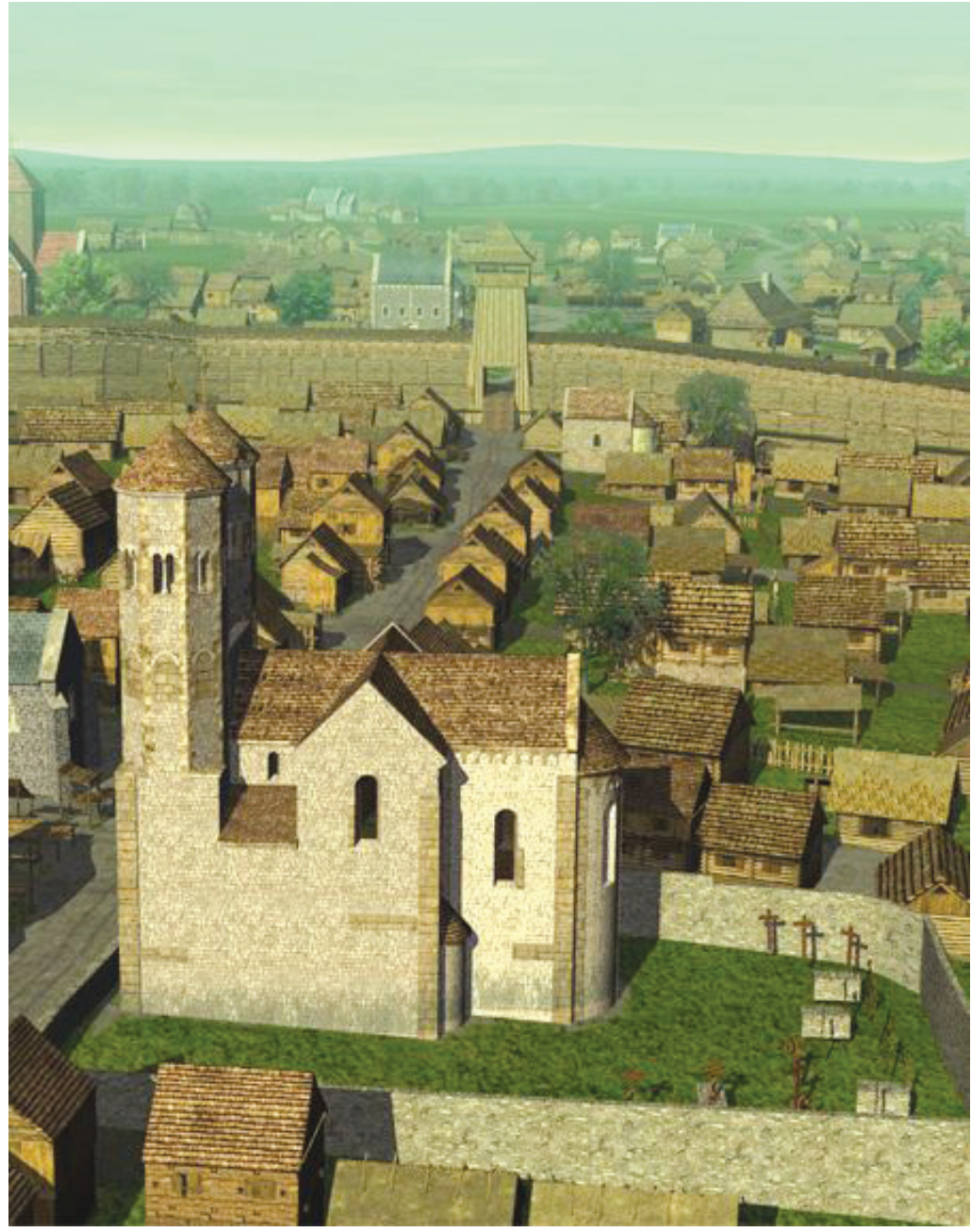

Fig. 3. Krakow, St Andrew's colegiate church and a model of the Krakow's borough in the middle of the $13^{\text {th }} \mathrm{c}$. (Reconstruction by Marcin Orkisz MM Interactive after [6]) 
Apart from the above considerations, in other chapters Fernie cites many Polish preRomanesque and Romanesque churches from outside Lesser Poland: Strzelno, Tum. He also draws attention to the sculptural decorations of Polish churches and in Lesser Poland the most prominent for him is Kościelec Proszowicki.

It should be emphasized that the author is well versed in the historical material and in Polish-language literature, which he introduces to international scholarly literature. It is rewarding for Polish readers that thanks to Professor Fernie, Polish pre-Romanesque and Romanesque architecture appears for the first time in English-speaking literature. It may have been created on the outskirts of the western empire but is certainly closely related to the artistic universum of Romanesque Europe. As the subtitle of the book indicates, the Romanesque was the first universal style connecting the vast and distant regions of Latin Europe.

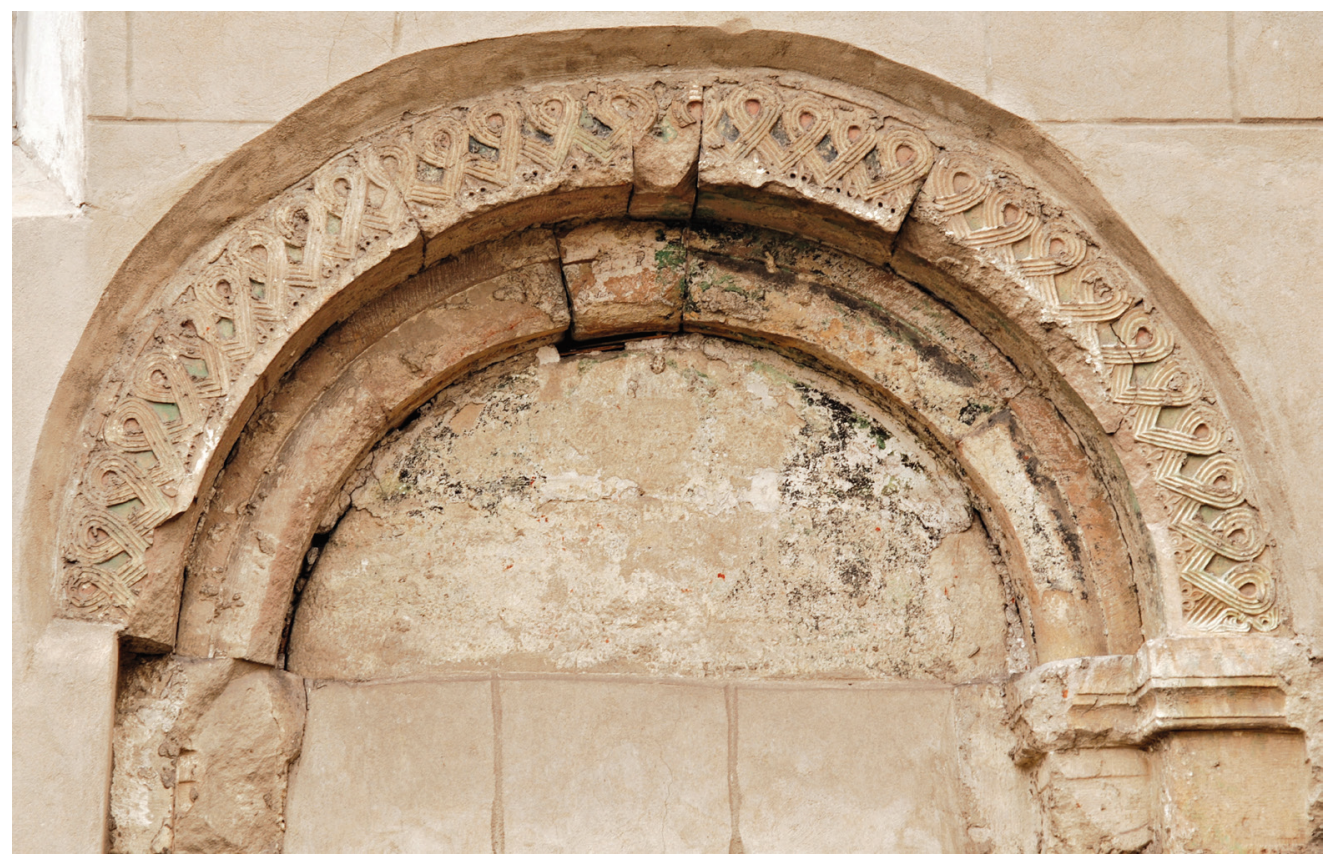

Fig. 4. Prandocin parochial church, an ornament on the portal arcade of the $12^{\text {th }} \mathrm{c}$. (photo by S. Dziuba)

\section{References}

[1] Conant K.J., Carolingian and Romanesque Architecture 800-1200, $1^{\text {st }}$ edition: Yale University Press, New Haven 1959 [Pelican History of Art].

[2] Crossley P., Bohemia Sacra and Polonia Sacra. Liturgy and History in Prague and Cracow Cathedrals. „Folia Historiae Artium, s.n.” 7, 2001.

[3] Crossley P., Gothic Architecture in the Reign of Kazimir the Great. Church Architecture in Lesser Poland 1320-1380, Kraków 1985 [Biblioteka Wawelska 7]. 
[4] Crossley P., Krakow Cathedral and the Formation of a Dynastic Architecture in Southern Central Europe, [in:] F. Ames-Lewis (ed.), Polish and English Responses to French Art and Architecture. Contrasts and Similarities. Papers delivered at the University of London/ University of Warsaw History of Art Conference, January and September 1993, London 1995.

[5] Fernie E., Romanesque Architecture: The First Style of the European Age, Yale University Press: New Haven and London 2014 [Pelican History of Art].

[6] Fernie E., The Church of St Andrew, Cracow, [in:] A Roznowska-Sadraei, T. Węclawowicz (ed.), Medieval Art, Architecture and Archaeology in Krakow and Lesser Poland, LondonLeeds 2014 [The British Archaeological Association Conference Transaction XXXVII].

[7] Gajewski A., Identity on the Edge: The Architecture of the Cistercian Abbeys in Lesser Poland, [in:] A Roznowska-Sadraei, T. Węclawowicz (ed.), Medieval Art, Architecture and Archaeology in Krakow and Lesser Poland, London-Leeds 2014 [The British Archaeological Association Conference Transaction XXXVII].

[8] Gajewski A., (Rezension aus) Ewa Luzyniecka, Zygmunt Swiechowski, Robert Kunkel The Architecture of Cistercian Abbeys. Morimond Filiation in Lesser Poland, Wroclaw 2008, "Kunst Chronik. Monatsschrift für Kunstwissenshaft Museumwesen und Denkmalpflege" 63/5, 2010.

[9] Mroczko T., Czerwińsk romański, Warszawa 1972.

[10] Mroczko T., Czerwiński uczeń Wiligelma, „Biuletyn Historii Sztuki” XXXIII, 1971.

[11] Opačić Z., Architecture and Ceremony in Cracow and Prague 1335-1455, [in:] A Roznowska-Sadraei, T. Węctawowicz (ed.), Medieval Art, Architecture and Archaeology in Krakow and Lesser Poland, London-Leeds 2014 [The British Archaeological Association Conference Transaction XXXVII].

[12] Roznowska-Sadraei A., Pater Patriae: The Cult of Saint Stanislaus and the Patronge of Polish Kings 1200-1455, Unum Publishing House: Krakow 2008.

[13] Roznowska Sadraei A., Weclawowicz T., (ed.), Medieval Art, Architecture and Archaeology in Krakow and Lesser Poland, London-Leeds 2014 [The British Archaeological Association Conference Transaction XXXVII].

[14] Sadraei A., The Tomb of Kazimir the Great in the Wawel Cathedral of Krakow, "Acta Historiae Artium Academiae Scientiarum Hungaricae”, 42, 2001.

[15] Weclawowicz T., Cocto latere nobilitavit: Ceglane mury gotyckich kościołów Krakowa, Kraków 2013.

[16] Weclawowicz T., Royal Cathedral Church on Wawel Hill in Krakow: Jubilee of the Consecration 1364-2014, Krakow 2014. 